\title{
Cell Cycle Delay, Pro-metaphase Arrest and C-metaphase Inducing Effects of Petroleum Ether Fraction of Leaf Aqueous Extract of Clerodendrum viscosum Vent.
}

\author{
Sujit Roy ${ }^{1}$, Lalit Mohan Kundu ${ }^{1,2}$, Gobinda Chandra Roy ${ }^{1,3}$, Manabendu Barman ${ }^{1}$ and Sanjib Ray ${ }^{1 *}$ \\ ${ }^{1}$ Molecular Biology and Genetics Unit, Department of Zoology, The University of Burdwan, Golapbag, Purba Bardhaman-713104, West Bengal, \\ India. \\ ${ }^{2}$ Department of Zoology, Kalna College. Kalna, West Bengal, India. \\ ${ }^{3}$ Department of Zoology, Dinhata College, Dinhata, Cooch Behar, West Bengal, India. \\ *Corresponding author, e-mail: sray@zoo.buruniv.ac.in
}

\section{Summary}

Clerodendrum viscosum is a traditionally used medicinal plant. The present study aimed to analyze cell cycle delay, pro-metaphase arrest, and c-metaphase inducing effects of the petroleum ether fraction (AQPEF) of leaf aqueous extract of C. Viscosum (LAECV). The LAECV was fractionated with petroleum ether and its metaphase arrest, cell cycle delay, and c-metaphase inducing activities were tested on A. cepa root tip cells. The AQPEF induced cell cycle delay, and colchicine like metaphase, c-metaphase, in A. cepa root tip cells. Thus, the present study explores AQPEF as an active fraction of LAECV having metaphase arresting, cell cycle delay, and c-metaphase inducing potentials.

Keywords: Diterpenoids; Mitotic abnormality; Allium cepa; Metaphase arrest.

Clerodendrum viscosum (Family: Lamiaceae) is widely distributed throughout Asia, Africa, Australia, and America. It is used in traditional, Ayurvedic, Homeopathic, and Unani medicine (Nandi and Lyndem 2015). The whole plant juice is used against worm infection, cough, itching, leprosy, scorpion sting, asthma, bronchitis, fever, etc. (Kirtikar and Basu 1991, Bhattacharjee 2011). The plant is well known for its effectiveness against rheumatism in Unani medicine (Singh et al. 1997). It is prescribed to treat postnatal complications, diarrhea, and fresh wounds in the Indian Homeopathic system (Hamilton 1997, Nadkarni and Nadkarni 2002). Its bark juice is used to relieve indigestion and abdominal pain. The different parts of this plant are used as a remedy for asthma, malaria, cataract, diseases of the skin, blood, and lung by the Indian Tribals of Chotanagpur plateau (Kirtikar and Basu 1991).

The plant's ethanolic extracts have antioxidant, antimicrobial, hepatoprotective, wound healing, and antidiarrheal activities (Bhattacharjee et al. 2011). The anthelmintic activity was reported in leaf ethanolic, methanolic, and aqueous extracts against Pheretima posthuma (Islam et al. 2013). The leaves and roots have great potential against different microbial and fungal strains. Acetone and chloroform extracts of $C$. viscosum leaves have an inhibitory effect on the growth of Shigella sp., Vibrio cholerae, Klebsiella pneumonia, and Pseudomonas aeruginosa, etc. (Lobo et al. 2010) while ethanolic fraction has shown antifungal activity against Aspergillus niger, A. flavus, and Candida albicans (Modi et al. 2010). A saponin isolated from petroleum ether extract of leaves has analgesic activity (Sannigrahi et al. 2009). In vivo, antinociceptive activity of the methanolic extract is comparable to diclofenac sodium drug (Rahman et al. 1970). Reduction in $\mathrm{CCl}_{4}$ induced hepatotoxicity on rats after treatment with methanolic leaf extract reveals its hepatoprotective activity which is further supported by biochemical blood parameters (Sannigrahi et al. 2009). Successive ethanolic extract of $C$. infortunatum shows the highest antioxidant activity compared to petroleum ether and chloroform extracts, whereas significant wound healing activity was exhibited by petroleum ether and ethanol extract. These pharmacological effects were also correlated with the total phenolic content of the plant (Gouthamchandra et al. 2010). Leaf methanolic extract exerts a restoring effect on blood glucose levels after streptozotocin treatment (Arvind et al. 2002, Das et al. 2011). Allelochemicals from leaf aqueous extract have been found to harm the growth and germination of weeds in agro-ecosystem (Qasem and Foy 2001, Devi et al. 2013). A promising positive correlation is established between the plant's parts and their insect repellent and insecticidal activity (Muh et al. 2014).

Acute toxicity test reveals that these plant parts are safe up to 2000 $\mathrm{mg} \mathrm{kg} \mathrm{kg}^{-1}$ body weight (Gupta et al. 2012). The crude leaf extracts contain phenolics viz. fumaric acids, acetoside, methyl esters of caffeic acids, terpenoids like clerodin, flavonoids such as apigenin, acacetin, scutellarein, quercetin, hispidulin, steroids such as clerodone, clerodolone, clerodol, clerosterol and some fix oils 
containing linolenic acid, oleic acids, stearic acid and lignoceric acid (Singhmura 2016).

In our previous study, we have reported that treatment with leaf aqueous extract of C. viscosum (LAECV) on root apical meristem cells of wheat and onion gave an increased metaphase frequency along with a reduction in mitotic index, antiproliferative, and apoptosis-inducing effects (Ray et al. 2012). The metaphase arrest and cell cycle delay-inducing effects were somewhat comparable to colchicine's action (Ray et al. 2013, Kundu and Ray 2016, Roy and Ray 2017).

Colchicine inhibits spindle formation in cells which leads to generating signals delaying the transition from metaphase to anaphase (Salmon et al. 1984). Later on, when the concentration of colchicine decreases in the environment, the chromatids separate abnormally and the plant cells become polyploid (Caperta et al. 2006). Colchicine treatment to onion root apical meristem cells results in root growth inhibition, root's swelling, haphazardly arranged condensed chromosomes, and increased frequency in metaphase (Ray et al. 2013). In another comparative study, colchicine and LAECV treatments on A. cepa root tip cells revealed similar cytotoxic effects (Kundu and Ray 2016). The metaphase arrest and cell cycle delayinducing effects of LAECV raised the key question about its active principle(s) (Ray et al. 2013). Therefore, this study aims to fractionate the bioactive molecule(s) of LAECV with non-polar petroleum ether solvent and to test its antiproliferative and metaphase arresting activities. The LAECV was fractionated with petroleum ether and the extract fraction was tested for cell cycle delay, pro-metaphase arrest, and c-metaphase inducing effects on A. cepa root tip cells.

\section{Materials and methods}

\section{Plant collection and extraction}

The fresh $C$. viscosum leaves were collected from Burdwan University campus, West Bengal, India, and it was taxonomically identified by Professor A. Mukherjee, Department of Botany, The University of Burdwan. A voucher specimen (No. BUTBSR011) is maintained in the Department of Zoology, B.U., for future reference. Fresh leaves were washed in tap water, dried in shade, ground by Philips Mixer Grinder HL1605, and the obtained powder was stored in a tightly sealed container for further use. $100 \mathrm{~g}$ of this pulverized material was extracted in $2.5 \mathrm{~L}$ of boiling distilled water for 2-3 $\mathrm{h}$ and the extract was filtered with filter paper and the extract coded as leaf aqueous extract of $C$. viscosum (LAECV). The LAECV was fractioned by petroleum ether with the help of a magnetic stirrer for 10-12 h. After collection by siphoning, the solvent fraction (AQPEF) was concentrated by rotary vacuum evaporator and stored in a glass container.

\section{Culture and treatment for root growth retardation}

$1 \%$ sodium hypochlorite mediated surface-sterilized $A$. серa bulbs were placed in 6-well plates containing distilled water and kept in the environmental test chamber for germination $\left(25-27^{\circ} \mathrm{C}\right.$, humidity $50 \%)$. The $48 \mathrm{~h}$ aged similar-sized $A$. cepa roots $(2-3 \mathrm{~cm}$ root length) were treated with $12.5,25,50,100$, and $150 \mu \mathrm{g} \mathrm{mL}^{-1}$ concentrations of AQPEF in $1 \%$ DMSO continuously for 24,48 , and $72 \mathrm{~h}$. The experiments were performed in triplicate.

Cell cycle delay and c-metaphase inducing effects analysis

The $48 \mathrm{~h}$ aged similar-sized A. cepa roots $(2-3 \mathrm{~cm})$ were treated with $50,100,150,200 \mu \mathrm{g} \mathrm{mL}^{-1}$ of AQPEF and $150 \mu \mathrm{g} \mathrm{mL}^{-1}$ of colchicine for 2 and $4 \mathrm{~h}$. The stock solution of the Petroleum ether fraction was prepared in DMSO for treatment. After 2 and $4 \mathrm{~h}$ exposure, 8-10 roots were fixed and processed for squash preparation following the standard procedure (Chaudhuri and Ray 2015). The remaining roots were allowed to grow further for another $16 \mathrm{~h}$ in distilled water (4h $\mathrm{T}+16 \mathrm{~h}$ RS) and subsequently, root tips were fixed. The control group, which had not received any treatment, was maintained in distilled water simultaneously with the treatment groups. The treated and untreated root tips were fixed in aceto-methanol (3 parts methanol: 1part glacial acetic acid) for $24 \mathrm{~h}$ and then hydrolyzed for $10 \mathrm{~min}$ in 1 $\mathrm{M} \mathrm{HCl}$ at $60 \square$. The roots were stained with $2 \%$ aceto-orcein and finally squashed in 45\% acetic acid (Sharma and Sharma 1999, Ray et $a l$. 2013). The well-spread areas of squashed roots were focused under the bright field light microscope for observation and scoring the cell division phase and c- metaphase frequencies.

\section{Scoring and statistical analysis}

In the case of squash preparation of A. cepa root apical meristem cells, at least three randomly coded slides were observed under the light microscope. Calculation of the mitotic index was done by counting the number of dividing cells per total cells scored for each concentration. Different cell phase frequencies, mitotic index, and cmetaphase cells were analyzed by $2 \mathrm{X} 2$ contingency $\chi 2$-test. Pearson correlation was analyzed using GraphPad Prism 8.4.3.

\section{Results and discussion}

The focus of the present investigation was to analyze cell cycle delay, metaphase arrest, and c-metaphase inducing effects of AQPEF in A. cepa root apical meristem cells. Many authors suggested that antiproliferative and cytotoxic effects of plant extracts or chemical substances can be evaluated using A. cepa root tip cells (Levan 1938, Bakare et al. 2000, 2012, 2013, Frescura et al. 2012). The root growth 
Table 1: Root growth retardation effect of AQPEF in A. cepa.

\begin{tabular}{|c|c|c|c|c|c|}
\hline \multirow[t]{2}{*}{$\begin{array}{l}\text { AQPEF } \\
\left(\mu \mathrm{g} \mathrm{mL}^{-1}\right)\end{array}$} & \multicolumn{3}{|c|}{$\begin{array}{c}\text { Root length }(\mathrm{cm}) \\
\text { (Root length retardation \%) }\end{array}$} & \multicolumn{2}{|c|}{$\begin{array}{c}\text { Growth rate }(\mathbf{c m} / \mathbf{2 4} \mathbf{h}) \\
\text { Growth rate retardation }(\%)\end{array}$} \\
\hline & $24 \mathrm{~h}$ & $48 \mathrm{~h}$ & $72 \mathrm{~h}$ & $48 \mathrm{~h}$ & $72 \mathrm{~h}$ \\
\hline $\mathbf{0}$ & $3.08 \pm 0.10$ & $4.32 \pm 0.10$ & $5.51 \pm 0.11$ & $1.24 \pm 0.10$ & $1.19 \pm 0.03$ \\
\hline 12.5 & $\begin{array}{c}2.57 \pm 0.07 \\
(16.51 \pm 0.39)\end{array}$ & $\begin{array}{c}3.37 \pm 0.04^{\mathrm{b}} \\
(22.00 \pm 0.83)\end{array}$ & $\begin{array}{c}3.73 \pm 0.10^{\mathrm{a}} \\
\left(32.92 \pm 1.01^{\mathrm{a}}\right)\end{array}$ & $\begin{array}{c}0.79 \pm 0.06^{\mathrm{b}} \\
\left(35.62 \pm 2.62^{\mathrm{b}}\right)\end{array}$ & $\begin{array}{c}0.36 \pm 0.11^{\mathrm{a}} \\
\left(69.87 \pm 5.05^{\mathrm{a}}\right)\end{array}$ \\
\hline 25 & $\begin{array}{c}2.38 \pm 0.08^{\mathrm{b}} \\
\left(22.68 \pm 0.87^{\mathrm{b}}\right)\end{array}$ & $\begin{array}{c}2.80 \pm 0.08^{\mathrm{a}} \\
\left(35.08 \pm 1.06^{\mathrm{a}}\right)\end{array}$ & $\begin{array}{c}3.09 \pm 0.12^{\mathrm{a}} \\
\left(43.92 \pm 1.32^{\mathrm{a}}\right)\end{array}$ & $\begin{array}{c}0.42 \pm 0.04^{\mathrm{a}} \\
\left(65.48 \pm 3.84^{\mathrm{a}}\right)\end{array}$ & $\begin{array}{c}0.28 \pm 0.06^{\mathrm{a}} \\
\left(75.98 \pm 2.95^{\mathrm{a}}\right)\end{array}$ \\
\hline 50 & $\begin{array}{c}2.17 \pm 0.07^{\mathrm{a}} \\
\left(29.59 \pm 1.52^{\mathrm{a}}\right)\end{array}$ & $\begin{array}{c}2.45 \pm 0.09^{\mathrm{a}} \\
\left(43.31 \pm 1.97^{\mathrm{a}}\right)\end{array}$ & $\begin{array}{c}2.59 \pm 0.18^{\mathrm{a}} \\
\left(52.94 \pm 1.87^{\mathrm{a}}\right)\end{array}$ & $\begin{array}{c}0.28 \pm 0.16^{\mathrm{a}} \\
\left(76.55 \pm 8.87^{\mathrm{a}}\right)\end{array}$ & $\begin{array}{r}0.14 \pm 0.03^{\mathrm{a}} \\
\left(87.91 \pm 1.58^{\mathrm{a}}\right)\end{array}$ \\
\hline 100 & $\begin{array}{c}1.80 \pm 0.08^{\mathrm{a}} \\
\left(41.64 \pm 1.33^{\mathrm{a}}\right)\end{array}$ & $\begin{array}{c}1.99 \pm 0.07^{\mathrm{a}} \\
\left(53.91 \pm 0.74^{\mathrm{a}}\right)\end{array}$ & $\begin{array}{c}2.13 \pm 0.07^{\mathrm{a}} \\
\left(61.38 \pm 0.78^{\mathrm{a}}\right)\end{array}$ & $\begin{array}{c}0.19 \pm 0.03^{\mathrm{a}} \\
\left(84.17 \pm 2.43^{\mathrm{a}}\right)\end{array}$ & $\begin{array}{c}0.13 \pm 0.02^{\mathrm{a}} \\
\left(88.50 \pm 1.05^{\mathrm{a}}\right)\end{array}$ \\
\hline 150 & $\begin{array}{c}1.50 \pm 0.06^{\mathrm{a}} \\
\left(51.33 \pm 1.31^{\mathrm{a}}\right) \\
\end{array}$ & $\begin{array}{r}1.63 \pm 0.05^{\mathrm{a}} \\
\left(62.31 \pm 0.44^{\mathrm{a}}\right)\end{array}$ & $\begin{array}{c}1.73 \pm 0.05^{\mathrm{a}} \\
\left(68.51 \pm 0.56^{\mathrm{a}}\right) \\
\end{array}$ & $\begin{array}{c}0.13 \pm 0.03^{\mathrm{a}} \\
\left(89.32 \pm 1.93^{\mathrm{a}}\right) \\
\end{array}$ & $\begin{array}{c}0.10 \pm 0.03^{\mathrm{a}} \\
\left(91.01 \pm 1.51^{\mathrm{a}}\right) \\
\end{array}$ \\
\hline
\end{tabular}

Allium cepa root growth retardation effect of the AQPEF was performed in triplicate and data analyzed with Student's t-test. ${ }^{a}$ significant at $p<0.001,{ }^{b}$ significant at $p<0.01$ and $^{\mathrm{c}}$ significant at $p<0.05$ as compared to their respective control by Student's $\mathrm{t}$-test. Data represented as Mean \pm SEM.

Table 2: Metaphase arrest and c-metaphase inducing effects of AQPEF.

\begin{tabular}{|c|c|c|c|c|c|c|c|c|c|}
\hline $\mathbf{h}$ & 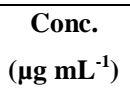 & Tc & Tdc & MI\% & Pro\% & Meta\% & Ana \% & Telo\% & C-Meta\% \\
\hline \multirow[t]{6}{*}{2} & 0 & 1959 & 111 & $5.67 \pm 0.30$ & $21.95 \pm 4.90$ & $36.86 \pm 2.97$ & $25.87 \pm 3.32$ & $15.13 \pm 0.70$ & $1.66 \pm 1.66$ \\
\hline & 50 & 2181 & 144 & $6.63 \pm 0.41$ & $16.67 \pm 1.27$ & $42.41 \pm 1.35$ & $25.64 \pm 4.45$ & $15.25 \pm 2.48$ & $22.18 \pm 1.52^{\mathrm{a}}$ \\
\hline & 100 & 2445 & 183 & $7.58 \pm 0.5^{\mathrm{c}}$ & $15.93 \pm 2.63$ & $56.52 \pm 1.96$ & $18.48 \pm 3.42$ & $11.09 \pm 0.94$ & $39.2 \pm 4.05^{\mathrm{a}}$ \\
\hline & 150 & 2404 & 234 & $9.76 \pm 0.26^{\mathrm{a}}$ & $16.32 \pm 1.01$ & $63.67 \pm 3.27^{\mathrm{c}}$ & $14.95 \pm 1.28$ & $5.05 \pm 1.76^{b}$ & $55.62 \pm 2.03^{\mathrm{a}}$ \\
\hline & 200 & 2389 & 251 & $10.51 \pm 0.80^{\mathrm{a}}$ & $17.74 \pm 1.90$ & $53.67 \pm 2.05$ & $17.96 \pm 2.23$ & $10.63 \pm 1.13$ & $45.15 \pm 3.86^{\mathrm{a}}$ \\
\hline & $150 \bigodot$ & 1987 & 248 & $12.55 \pm 1.44^{\mathrm{a}}$ & $11.91 \pm 1.41$ & $79.75 \pm 4.46^{\mathrm{a}}$ & $5.98 \pm 2.74^{\mathrm{a}}$ & $2.32 \pm 0.49^{\mathrm{a}}$ & $77.95 \pm 5.63^{\mathrm{a}}$ \\
\hline \multirow[t]{6}{*}{4} & 0 & 2914 & 207 & $7.09 \pm 0.62$ & $19.02 \pm 0.97$ & $37.72 \pm 2.60$ & $30.77 \pm 2.07$ & $12.45 \pm 0.51$ & $0.00 \pm 0.00$ \\
\hline & 50 & 3423 & 352 & $10.3 \pm 0.56^{\mathrm{a}}$ & $8.72 \pm 2.61^{\mathrm{b}}$ & $66.47 \pm 5.70^{\mathrm{a}}$ & $14.54 \pm 1.98^{\mathrm{a}}$ & $10.24 \pm 2.27$ & $49.38 \pm 5.71^{\mathrm{a}}$ \\
\hline & 100 & 2162 & 222 & $10.3 \pm 0.29^{a}$ & $10.04 \pm 1.61^{\mathrm{c}}$ & $81.44 \pm 1.61^{\mathrm{a}}$ & $6.67 \pm 1.04^{\mathrm{a}}$ & $1.83 \pm 0.52^{\mathrm{a}}$ & $80.08 \pm 1.65^{\mathrm{a}}$ \\
\hline & 150 & 3035 & 403 & $13.25 \pm 0.72^{\mathrm{a}}$ & $9.34 \pm 1.11^{\mathrm{c}}$ & $78.48 \pm 2.41^{\mathrm{a}}$ & $8.76 \pm 2.53^{\mathrm{a}}$ & $3.39 \pm 0.76^{\mathrm{a}}$ & $70.86 \pm 2.74^{\mathrm{a}}$ \\
\hline & 200 & 3525 & 352 & $9.95 \pm 0.80^{\mathrm{a}}$ & $14.33 \pm 2.74$ & $76.43 \pm 2.61^{\mathrm{a}}$ & $8.00 \pm 0.27^{\mathrm{a}}$ & $2.26 \pm 0.48^{\mathrm{a}}$ & $68.88 \pm 1.67^{\mathrm{a}}$ \\
\hline & $150 \bigodot$ & 3286 & 301 & $9.17 \pm 0.56^{b}$ & $9.35 \pm 1.92^{b}$ & $84.88 \pm 1.26^{\mathrm{a}}$ & $4.70 \pm 0.63^{\mathrm{a}}$ & $1.00 \pm 0.07^{\mathrm{a}}$ & $83.00 \pm 1.93^{\mathrm{a}}$ \\
\hline \multirow[t]{6}{*}{$4+16$} & 0 & 2449 & 241 & $10.06 \pm 0.92$ & $24.63 \pm 2.84$ & $38.95 \pm 0.78$ & $23.27 \pm 0.93$ & $13.11 \pm 2.99$ & $0.00 \pm 0.00$ \\
\hline & 50 & 3946 & 276 & $7.00 \pm 0.29^{\mathrm{a}}$ & $14.83 \pm 0.34^{\mathrm{c}}$ & $45.32 \pm 0.66$ & $24.58 \pm 0.94$ & $15.23 \pm 0.43$ & $0.36 \pm 0.36^{\mathrm{a}}$ \\
\hline & 100 & 2130 & 177 & $8.45 \pm 1.64$ & $12.77 \pm 3.18^{\mathrm{c}}$ & $65.69 \pm 3.87^{\mathrm{b}}$ & $12.23 \pm 0.72^{\mathrm{c}}$ & $9.28 \pm 1.71$ & $43.05 \pm 13.28^{\mathrm{a}}$ \\
\hline & 150 & 2068 & 136 & $6.51 \pm 0.77^{\mathrm{a}}$ & $20.08 \pm 0.92$ & $52.42 \pm 6.02$ & $18.64 \pm 2.49$ & $8.82 \pm 3.99$ & $33.73 \pm 1.91^{\mathrm{a}}$ \\
\hline & 200 & 2162 & 161 & $7.43 \pm 0.38^{\mathrm{b}}$ & $25.00 \pm 2.85$ & $35.78 \pm 2.46$ & $29.68 \pm 2.72$ & $9.51 \pm 2.22$ & $24.81 \pm 5.00^{\mathrm{b}}$ \\
\hline & $150 \odot$ & 1922 & 69 & $3.55 \pm 1.10^{\mathrm{a}}$ & $23.35 \pm 3.40$ & $38.81 \pm 1.66$ & $11.60 \pm 2.05$ & $26.20 \pm 3.57$ & $9.96 \pm 3.40^{\mathrm{a}}$ \\
\hline
\end{tabular}

${ }^{a}$ Significant at $p<0.0001,{ }^{\mathrm{b}}$ significant at $p<0.001$ and ${ }^{\mathrm{c}}$ significant at $p<0.05$ as compared with their respective control by $2 \times 2$ Contingency $\chi 2$ test with respective $d f=1$. h; Hours, Comp; Compound, Conc; Concentration, Tc; Total no of cells, Tdc; Total no of dividing cells, MI; Mitotic 
bioRxiv preprint doi: https://doi.org/10.1101/2020.11.29.402370; this version posted August 22, 2021. The copyright holder for this preprint (which was not certified by peer review) is the author/funder. All rights reserved. No reuse allowed without permission.

index, Pro; Prophase, Meta; Metaphase, LAECV; Leaf aqueous extract of C. viscosum, h; hour, Anaphase, Ana; Telo; Telophase, C-Meta; Colchicine like metaphase or C- metaphase, AQPEF; Petroleum ether fraction of LAECV, @; Colchicine. Data represented as Mean \pm SEM.
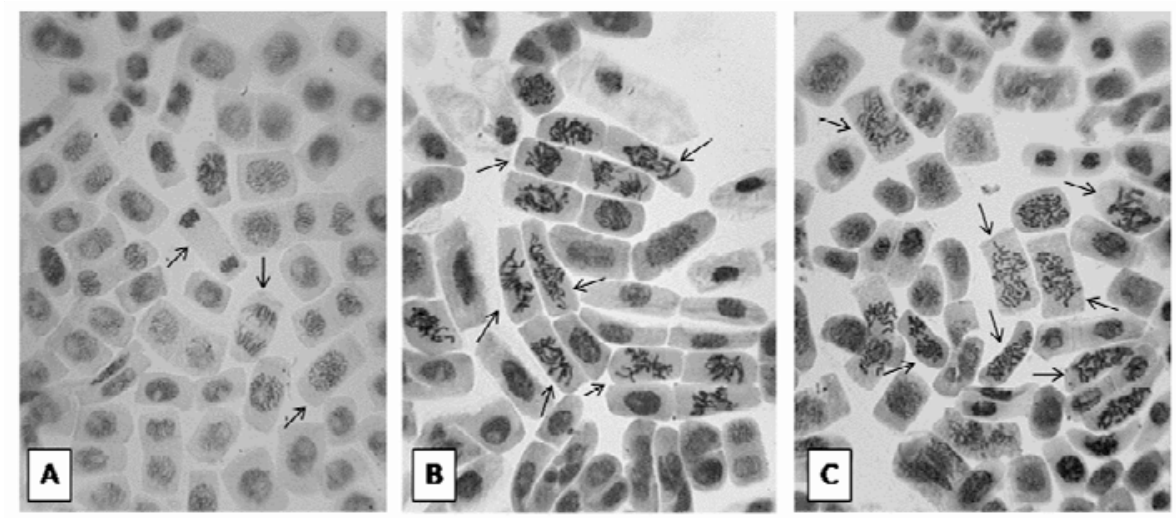

Fig. 1: Photomicrograph showing the squash preparation of A, Untreated; B, AQPEF (petroleum ether fraction); C, Colchicine induced increased C-metaphase frequency in root apical cells of $A$. cepa at $4 \mathrm{~h}$ continuous treatment.
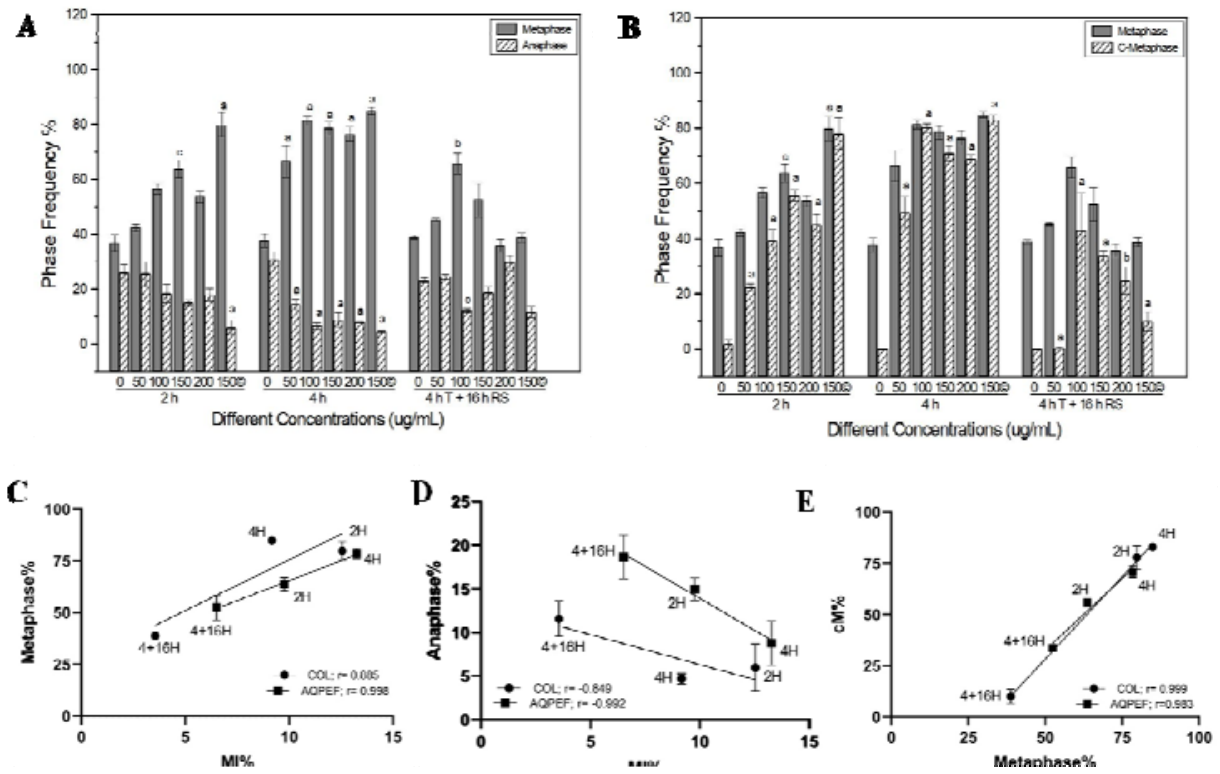

Fig. 2: Graph showing the effect of AQPEF and Colchicine on A, metaphase and anaphase frequency; B, metaphase and C-metaphase frequency. Data represented as mean \pm sem. ${ }^{\text {a }}$ significant at $p<0.0001$ and ${ }^{\mathrm{b}}$ significant at $p<0.001,{ }^{\mathrm{c}}$ significant at $p<0.05$ as compared to their respective control by $2 \times 2$ Contingency $\chi 2$-test with respective $\mathrm{d} f=1$. Pearson Correlation and simple linear regression analysis of Colchicine $\left(150 \mu \mathrm{g} \mathrm{mL} L^{-1}\right)$

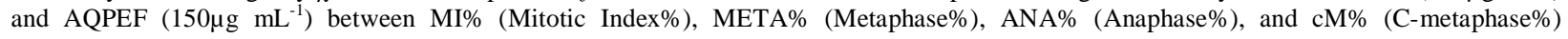
considering the change in their relative percentages at $2 \mathrm{~h}, 4 \mathrm{~h}$ and $4 \mathrm{~h} \mathrm{~T}+16 \mathrm{~h} \mathrm{RS}$. C, MI\% and Metaphase\%; D, MI\% and Anaphase\%; E, Metaphase $\%$ and $\mathrm{cM} \%$.

retardation depends on the antiproliferative potentials of the treated substances. Data indicate that AQPEF induced a concentrationdependent $A$. серa root growth retardation effect. The highest root length retardation percentage $(68.51 \pm 0.56 \%, p<0.001)$ in $150 \mu \mathrm{g} \mathrm{mL}^{-1}$ at $72 \mathrm{~h}$ of $\mathrm{AQPEF}$ treatment and $\mathrm{IC}_{50}$ value of the root growth retardation was $23.68 \pm 5.5 \mu \mathrm{g} \mathrm{mL}^{-1}$ at $48 \mathrm{~h}$ treatment (Table 1). Recently, Barman et al. (2020) and Das et al. (2021) reported that plant extract induced root growth retardation and the levels of root growth retardation were increased with the increasing extract concentration and suppression of cell division in A. сера root tips (Murthy et al. 2011, Ray et al. 2013). For the determination of 
antiproliferative and cytotoxic potentials of synthetic or biochemicals including plant extracts, the A. cepa test model is widely used (Frescura et al. 2013, Khanna et al. 2013).

The mitotic index percentage in root apical meristem cells varies with the growing periods and the used AQPEF concentrations. Here, the highest MI (13.25 $\pm 0.72 \%)$ was scored at $4 \mathrm{~h}$ of AQPEF $(150 \mu \mathrm{g} \mathrm{mL}$ $\left.{ }^{1}\right)$ treatment and the lowest MI $(3.55 \pm 1.10 \%)$ was found in the case of colchicine $\left(150 \mu \mathrm{g} \mathrm{mL}^{-1}\right)$ at $4 \mathrm{~h}$ followed by $16 \mathrm{~h}$ recovery samples. At $2 \mathrm{~h}, \mathrm{MI} \%$ values were gradually increased-5.67 $\pm 0.30,6.63 \pm 0.41$, $7.58 \pm 0.5,9.76 \pm 0.26$, and $10.51 \pm 0.80 \%$ respectively for $0,50,100$, 150 , and $200 \mu \mathrm{g} \mathrm{mL}^{-1}$. The MI\% also increased in the case of $4 \mathrm{~h}$ treated samples - 7.09 $\pm 0.62,10.3 \pm 0.56,10.3 \pm 0.29,13.25 \pm 0.72$, and $9.95 \pm 0.80 \%$ respectively for $0,50,100,150$, and $200 \mu \mathrm{g} \mathrm{mL}{ }^{-1}$ of AQPEF. In the case of $16 \mathrm{~h}$ recovery samples ( $4 \mathrm{~h} \mathrm{~T}+16 \mathrm{~h}$ RS), MI\% values were $10.06 \pm 0.92,7.00 \pm 0.29,8.45 \pm 1.64,6.51 \pm 0.77$, and $7.43 \pm 0.38 \%$ respectively for $0,50,100,150$ and $200 \mu \mathrm{g} \mathrm{mL}{ }^{-1}$ of AQPEF. In the case of $150 \mu \mathrm{g} \mathrm{mL}^{-1}$ colchicine treatment, data indicate the MI\% decreasing tendencies at $2 \mathrm{~h}(12.55 \pm 1.44 \%), 4 \mathrm{~h}$ $(9.17 \pm 0.56 \%)$ and $4 \mathrm{~h}$ followed by $16 \mathrm{~h}$ recovery samples $(3.55 \pm 1.10 \%)$. Plant extracts having mitostatic effects can be regarded as cytogenotoxic substance (Frescura et al. 2013, Khanna et al. 2013) and the reduction in the mitotic index is considered as an important parameter to examine the antimitotic as well as cytotoxic effects of biochemicals. The reduction in MI may be the result of their cytotoxic effects like blockage during DNA synthesis or $\mathrm{G}_{2}$ phase or insufficient synthesis of ATP during spindle fiber formation and elongation (Sreeranjini and Siril 2011).

The investigation by squash preparation of A. cepa root apical meristem cells revealed that AQPEF induced increased metaphase frequencies and decreased frequencies of prophase, anaphase, and telophase in a concentration-dependent manner at both 2 and $4 \mathrm{~h}$ treated samples indicate that AQPEF has definite metaphase arresting activity. Subsequently, in recovery root tip cells $(4 \mathrm{~h} \mathrm{~T}+16 \mathrm{~h}$ RS), the frequencies of prophase, anaphase, and telophase showed an increasing tendency as compared to 2 and $4 \mathrm{~h}$ treated cells (Table 2). The highest metaphase cells percentage $(81.44 \pm 1.61 \%)$ was scored from $4 \mathrm{~h} \mathrm{AQPEF}$ treated $\left(100 \mu \mathrm{g} \mathrm{mL} \mathrm{m}^{-1}\right)$ samples and that was followed by the concentration of $150 \mu \mathrm{g} \mathrm{mL} \mathrm{m}^{-1}(78.48 \pm 2.41 \%)$. However, in the case of $16 \mathrm{~h}$ recovery samples, the metaphase frequency showed a reducing tendency, and the metaphase frequencies were scored as $65.69 \pm 3.87 \%$ and $52.42 \pm 6.02 \%$ respectively for 100 and $150 \mu \mathrm{g} \mathrm{mL} \mathrm{m}^{-1}$ of AQPEF. Similarly. Colchicine treatment for 2 and $4 \mathrm{~h}$ notably induced increased metaphase frequency, $79.75 \pm 4.46 \%$, and $84.88 \pm 1.26 \%$ respectively. In the case of $16 \mathrm{~h}$ recovery after $4 \mathrm{~h}$ colchicine treatment, the metaphase frequency $(38.81 \pm 1.66 \%)$ was comparable to untreated control (Table 2). The mitotic index elevation in 2 and $4 \mathrm{~h}$ treated cells may be due to an increase in metaphase frequencies. A similar colchicine-induced change in mitotic index and metaphase frequencies was observed earlier (Davidson et al. 1966).

Data indicate that the $\mathrm{C}$-metaphase is the most frequent type of abnormalities induced by AQPEF in A. cepa root apical meristem cells. The AQPEF and colchicine treatments for 2 and $4 \mathrm{~h}$ induced a significant $(p<0.001 \& 0.0001)$ increase in the frequency of $\mathrm{C}$ metaphase in A. cepa root apical meristem cells in a concentrationdependent manner and decreased in recovery treatments (Table 2, Fig. 1,2). In the case of $2 \mathrm{~h}$ treatment, $150 \mu \mathrm{gL}^{-1}$ of AQPEF showed the highest C-metaphase frequency $(55.62 \%)$ but in the case of $4 \mathrm{~h}$ treatment, $100 \mu \mathrm{g} \mathrm{mL}^{-1}$ of AQPEF induced the highest (80.08\%) Cmetaphase. Similarly, C-metaphase frequency was also increased in colchicine $\left(150 \mu \mathrm{g} \mathrm{mL}^{-1}\right)$ treated samples as $77.95 \pm 5.63 \%$ and $83.00 \pm 1.93 \%$ respectively for 2 and $4 \mathrm{~h}$. In the case of $16 \mathrm{~h}$ recovery samples (4 h T +16 h RS), c-metaphase frequency $(9.96 \pm 3.40 \%)$ was decreased. The formation of C-metaphase is directly correlated with the microtubule disruption and indicates that phytochemicals present in AQPEF may have colchicine-like microtubule destabilizing activity (FiskesjÖ 1985, Bonciu et al. 2018, Shahin and El-Amoodi 1991). These data also correlate with the occurrence of C-metaphase in LAECV and colchicine-treated A. cepa root tip cells (Kundu and Ray 2016). Recently, Barman et al. (2021) reported colchicine like $C$. inerme leaf aqueous extract, LAECI, induced haphazardly arranged condensed chromosomes, C-metaphase, in A. cepa. Correlation between the formation of $\mathrm{C}$-metaphase, vagrant chromosome, and polyploidy was evident by many investigators in A. cepa root tip cells (Carvalho et al. 2019). Based on this correlative evidence, we can postulate that AQPEF has a similar effect to LAECV on A. cepa root tip cells.

From Pearson correlation and simple linear regression analysis of colchicine $\left(150 \mu \mathrm{g} \mathrm{mL}^{-1}\right)$ and AQPEF $\left(150 \mu \mathrm{g} \mathrm{mL}^{-1}\right)$ between MI\% (Mitotic Index\%), META\% (Metaphase\%), ANA\% (Anaphase\%), and $\mathrm{cM} \%$ (C-metaphase\%) considering the change in their relative percentages at 2,4 , and $4 \mathrm{~h} \mathrm{~T}+16 \mathrm{~h} \mathrm{RS}$, a positive correlation was drawn between MI \% and META \%whereas a negative correlation was found between MI \% and ANA \% both in colchicine ( $\mathrm{r}=0.885$ in META\% and $r=-0.849$ in ANA\%) and AQPEF ( $r=0.998$ in META\% and $r=-0.992$ in ANA\%). Positive correlation was also drawn between META\% and cM\% in AQPEF ( $r=0.983)$ and colchicine (0.999). The above observations indicate that an increase in metaphase frequency was correlated with the decrease in anaphase frequency of both colchicine and AQPEF treatment. It can be extrapolated as the metaphase arresting nature of colchicine and AQPEF, leads to an increase in metaphase frequency and a simultaneous decrease in anaphase frequency, a possible mechanism for the cell cycle delay. A positive correlation between META\% and 
$\mathrm{cM} \%$ indicate that both compounds possess metaphase arresting activity; therefore, AQPEF may have colchicine-like microtubule destabilizing attributes (Fig.2). The LAECV and its petroleum ether fraction, AQPEF, has colchicine-like metaphase arrest and mitotic abnormalities inducing potentials (Ray et al. 2012, Kundu and Ray 2016, Roy et al. 2021) and this study indicates AQPEF has cell cycle delay, metaphase arrest, c-metaphase inducing potentials in A. cepa root apical meristem cells. A further detailed investigation is required for purification of active principles of $C$. viscosum and to test their relative cell cycle delay, pro-metaphase arrest, and mitotic abnormality-inducing potentials.

Disclosure statement

No conflict of interest was declared.

\section{Acknowledgments}

The authors acknowledge Prof. A. Mukherjee for plant species authentication and the financial support of UGC-SRF (FC(Sc)/RS/UGC/ZOO/2018-19/129, w.e.f. 07.04.2018, dated: 04.02.2019), and the DST-PURSE, DST-FIST, and UGC-DRS-MRPsponsored facilities in the Department of Zoology.

References

Arvind, K., Pradeep, R., Deepa, R. and Mohan, V. 2002. Diabetes and coronary artery diseases. Indian J. Med. Res.116: 163-176.

Bakare, A.A., Adeyemi, A. O., Adeyemi, A., Alabi, O. A. and Osibanjo, O. 2012. Cytogenotoxic effects of electronic waste leachate in Allium cepa. Caryologia. 65: 94-100.

Bakare, A. A., Alabi, O. A., Gbadebo, A. M., Ogunsuyi, O. I. and Alimba, C. G. 2013. In vivo cytogenotoxicity and oxidative stress induced by electronic waste leachate and contaminated well water. Challenges. 4:169-187.

Bakare, A. A., Mosuro, A. A. and Osibanjo, O. 2000. Effect of simulated leachate on chromosomes and mitosis in roots of Allium cepa (L). J. Environ. Biol. 21: 263-271.

Barman, M., Roy, S. and Ray, S. 2020. Colchicine like metaphase and cell cycle delay inducing effects of leaf aqueous extract of Clerodendrum inerme L. Gaertn. in Allium cepa root apical meristem cells. Cytologia. 85: 197-201.

Barman, M., Roy, S. and Ray, S. 2020. Mitotic abnormality inducing effects of leaf aqueous extract of Clerodendrum inerme Gaertn. on Allium сера root apical meristem cells. Cytologia. 86: 113-118.

Bhattacharjee, D., Das, A., Das, S.K. and Chakraborthy, G.S. 2011. Clerodendrum infortunatum L.: A review. J. Adv. Pharm. Healthcare Res. 1: 82-5.
Bonciu, E., Firbas, P., Fontanetti, C. S., Wusheng, J., Karaismailoğlu, M. C., Liu, D., Menicucci, F., Pesnya, D. S., Popescu, A., Romanovsky, A. V. and Schiff, S. 2018. An evaluation for the standardization of the Allium cepa test as cytotoxicity and genotoxicity assay. Caryologia. 71: 191-209.

Caperta, A. D., Delgado, M., Ressurreicao, F., Meister, A., Jones, R. N., Viegas, W. and Houben, A. 2006. Colchicine-induced polyploidization depends on tubulin polymerization in cmetaphase cells. Protoplasma. 227: 147-153.

Carvalho, M. S., Andrade-Vieira, L. F., dos Santos, F. E., Correa, F. F., das Graças Cardoso, M. and Vilela, L. R. 2019. Allelopathic potential and phytochemical screening of ethanolic extracts from five species of Amaranthus spp. in the plant model Lactuca sativa. Sci. Hortic. 9: 90-8.

Chaudhuri, A. and Ray, S. 2015. Antiproliferative activity of phytochemicals present in aerial parts aqueous extract of Ampelocissus latifolia (Roxb.) Planch. on apical meristem cells. Int. J. Pharm. Bio. Sci. 6: 99-108.

Das, R., Goswami, S., Barman, A., Barman, M. and Ray, S. 2021. Antimitotic and cytotoxic effects of leaf aqueous extract of Scadoxus multiflorus (Martyn) Raf. in Allium cepa root apical meristem cells. Cytologia. 86:

Das, S., Bhattacharya, S., Prasanna, A., Kumar, RBS., Pramanik, G. and Halder, PK. 2011. Preclinical evaluation of antihyperglycemic activity of Clerodendrum infortunatum leaf against streptozotocin-induced diabetic rats. Diabetes ther. 2: 92-100.

Davidson, D., MacLeod, R. and O'Riordan, M. 1966. Changes in mitotic index induced by colchicine. Nature. 212: 15411542.

Devi, O. I., Dutta, B. K. and Choudhury, P. 2013. Allelopathy effect of aqueous extract of Clerodendrum viscosum Vent, Ageratum conyzoides and Parthenium hysterophorus on the seed germination and seedling vigour of chickpea seeds (Cicer arietinum L) in vitro. J. Nat. Appl. Sci.5: 37-40.

Fiskesjö, G. 1985. The Allium tests as a standard in environmental monitoring. Hereditas. 102: 99-112.

Frescura, V. D., Laughinghouse, H. D. $4^{\text {th }}$. and Tedesco SB. 2012. Antiproliferative effect of the tree and medicinal species Luehea divaricata on the Allium cepa cell cycle. Caryologia. 65: 27-33.

Frescura, V. D., Kuhn, A. W., Laughinghouse, H. D. $4^{\text {th }}$., Paranhos, J. T. and Tedesco, S. B. 2013. Post-treatment with plant extracts used in Brazilian folk medicine caused a partial reversal of the antiproliferative effect of glyphosate in the Allium cepa test. Biocell. 37: 23-28. 
Gouthamchandra, K., Mahmood, R. and Manjunatha H. 2010. Free radical scavenging, antioxidant enzymes and wound healing activities of leaves extracts from Clerodendrum infortunatum L. Environ. Toxicol. Pharmacol. 30: 11-18.

Gupta, R. and Singh, H. K. 2012. Nootropic potential of Alternanthera sessilis and Clerodendrum infortunatum leaves on mice. Asian Pac. J. Trop. Dis. 2: 465-470.

Hamilton, F. 1997. The Flora Homoeopathica. B Jain (New Delhi).

Islam, Md. S., Moghal, Md. M.R., Ahamed, S.K., Ahmed, J. and Islam, Md. A. 2013. A study on cytotoxic and anthelmintic activities of crude extracts of leaves of Clerodendrum viscosum. Int. Res. J. Pharm. 4: 99-102.

Khanna, N. and Sharma, S. 2013. Allium cepa root chromosomal aberration assay: a review. Indian J. Pharm. Biol. Res.1: 105-119.

Kirtikar, K.R. and Basu, B. D. 1991. Indian Medicinal Plants.III.2nd ed. Bishen Singh and Mahendra Pal Singh. Dehradun.

Kundu, L. M. and Ray, S. 2016. Mitotic abnormalities and micronuclei inducing potentials of colchicine and leaf aqueous extracts of Clerodendrum viscosum Vent. in Allium cepa root apical meristem cells. Caryologia. 70: 7-14

Levan, A. 1938. The effect of colchicine on root mitoses in Allium. Hereditas. 24: 471-86.

Lobo, R., Chandrshakar, K. S., Jaykumar, B. and Mamatha B. 2010. In vitro antimicrobial activity of Clerodendrum viscosum Vent. Der Pharm. Lett. 2: 257-260.

Modi, A. J., Khadabadi, S. S., Farooqui, I. A. and Ghorpade, D.S. 2010. Studies on antimicrobial activity of Clerodendrum infortunatum, Argyreia nervosa and Vitex negundo: A comparison. Der Pharm. Lett. 2: 102-105.

Muh, T., Waliullah, A., Yeasmin, A. M., Wahedul, I. M. and Parvez, H. 2014. Insecticidal and repellent activity of Clerodendrum viscosum Vent. (Verbenaceae) against Tribolium castaneum (Herbst) (Coleoptera: tenebrionoidea). Acad. J. Entomol. 7: 63-69.

Murthy, G.S., Francis, T.P., Singh, C.R., Nagendra, H.G. and Naik, C. 2011. An assay for screening anti-mitotic activity of herbal extracts. Curr. Sci. 100: 1399-1404.

Nadkarni, K. M. and Nadkarni, A. K. 2002. Indian Materia Medica. Bombay.

Nandi, S. and Lyndem, L. M. 2015. Clerodendrum viscosum: traditional uses, pharmacological activities and phytochemical constituents. Nat. Prod. Res. 30: 497-506.

Qasem, J. R. and Foy, C. L. 2001. Weed allelopathy, its ecological impacts and future prospects. J. Crop. Prod. 4: 43-119.
Ray, S., Kundu, L. M., Goswami, S. and Chakrabarti, C. S. 2012. Antiproliferative and apoptosis inducing activity of allelochemicals present in leaf aqueous extract of traditionally used antitumor medicinal plant, Clerodendrum viscosum Vent. Int. J. Pharm. Res. Dev. 4: 332-345.

Ray, S., Kundu, L. M., Goswami, S., Roy, G. C., Chatterjee, S., Dutta, S., Chaudhuri, A. and Chakrabarti, C. S. 2013. Metaphase arrest and delay in cell cycle kinetics of root apical meristems and mouse bone marrow cells treated with leaf aqueous extract of Clerodendrum viscosum Vent. Cell Prolif. 46: 109-117.

Roy, G. C. and Ray, S. 2017. Antiproliferative and apoptosis inducing activities of Leaf organic solvent extract fractions of Clerodendrum viscosum Vent. Int. J. Pharma. Bio Sci. 8: 5866.

Roy, S., Kundu, L.M., Roy, G.C., Barman, M. and Ray S. 2021. Cytotoxic and micronuclei inducing effects of petroleum ether fraction of leaf aqueous extract of Clerodendrum viscosum Vent. in Allium cepa root tip cells. Cytologia. 86: $1-6$.

Salmon, E. D., Mickseel, M. and Hays, T. 1984. Rapid rate of tubulin dissociation from microtubule in the mitotic spindle in vivo measured by blocking polymerization with colchicine. $J C B$. 99: 1066-1075.

Sannigrahi, S., Mazumder, U. K., Pal, D. K. and Mishra, S. L. 2009. Hepatoprotective potential of methanol extract of Clerodendrum infortunatum Linn. against $\mathrm{CCl}_{4}$ induced hepatotoxicity in rats. Pharmacogn. Mag. 5: 394-399.

Shahin, S. A. and El-Amoodi, K. H. H. 1991. Induction of numerical chromosomal aberrations during DNA synthesis using the fungicides nimrod and rumigan-4 in root tips of Vicia faba $\mathrm{L}$. Mutat. Res. 261: 169-176.

Sharma, A. K., and Sharma, A. 1999. Plant Chromosomes: Analysis, Manipulation and Engineering. Hardwood Academic Publishers.

Singh, V. K., Ali, Z. A. and Siddiqui, M. K. 1997. Medicinal plants used by the forest ethnics of Gorakhpur district (Uttar Pradesh), India. Int. J. Pharm. 35: 194-206.

Singhmura, S. 2016. A comprehensive overview of a traditional medicinal herb: Clerodendrum infortunatum Linn. J. pharm. sci. 5: 80-84.

Sreeranjini, S. and Siril, E. A. 2011. Evaluation of anti-genotoxicity of the leaf extracts of Morinda citrifolia L. Plant. Soil. Environ. 57: 222-227. 